\title{
Clinical infection in burn patients and its consequences
}

\author{
Cem Emir Güldoğan, M.D., ${ }^{1}$ Murat Kendirci, M.D., ${ }^{2}$ Deniz Tikici, M.D., ${ }^{3}$ \\ Emre Gündoğdu, M.D., ${ }^{4}$ Ahmet Çınar Yastı, M.D. ${ }^{2,3}$

\begin{abstract}
${ }^{1}$ Department of General Surgery, Altınbaş University Faculty of Medicine, İstanbul-Turkey
${ }^{2}$ Department of General Surgery, Hitit Univesity Faculty of Medicine, Çorum-Turkey

${ }^{3}$ Department of General Surgery, Ankara Numune Training and Research Hospital, Ankara-Turkey

${ }^{4}$ Department of General Surgery, Bahçeşehir University Faculty of Medicine, Liv Hospital, Ankara-Turkey
\end{abstract}

\begin{abstract}
BACKGROUND: Burn injuries facilitate invasive infections and sepsis not only by destroying the continuity of the protective skin barrier but also through systemic effects. The burn wound, blood, and urine samples are frequently cultured to determine the pathogen agent. The aim of this study was to analyze pathogen growth in patients' cultures confirmed as "infection positive" by the hospital Infection Control Committee and to assess the clinical implications of these growths.
\end{abstract}

METHODS: Hospitalized patients included in the study were those with a total burned body surface area of $>10 \%$ and "presence of infection" confirmed by the Infection Control Committee. The patients were evaluated with respect to age, gender, burn etiology, the total body surface area burned (TBSA), the presence of inhalation injury, sepsis, positive cultures, the microorganisms cultured in wound-blood-urine samples, and septic focus.

RESULTS: Of the total 36 (10.3\%) "infection-positive" patients, 26 (72.2\%) were male; the mean age of patients was $44 \pm 21$ years. The mean burned TBSA of the whole group was $45.58 \% \pm 23.1 \%$. Acinetobacter baumannii was the most isolated organism in the wound cultures. In patients with confirmed infection, there was a correlation between the pathogen isolated in urine cultures and mortality rates $(p=0.023)$. Sepsis was diagnosed in $23(63.9 \%)$ patients, of whom 21 had inhalation injuries. There was a significant correlation between inhalation injury and sepsis $(p=0.015)$, and both the presence of sepsis or inhalation injury increased mortality $(p=0.027$ and $p=0.009$, respectively).

CONCLUSION: According to the study data, the TBSA burned demonstrated a greater significance for mortality, although the presence of sepsis and/or urinary tract infection should also be noted as a cause of mortality in burned patients.

Keywords: Acinetobacter baumannii; Candida albicans; infection; sepsis.

\section{INTRODUCTION}

Burn injuries constitute hard-to-manage trauma both for the patients and physicians due to the development of many complications following the injury, the treatment process, and even after wound healing. One of the major functions of the body skin is to ensure protection against microorganisms in the external environment. When burn injuries occur, this integrity is destroyed, thereby facilitating penetration of micro-

Address for correspondence: Cem Emir Güldoğan, M.D. Bestekar Sok., No: 8, 06680 Kavaklıdere, Çankaya, Ankara, Turkey Tel: +90 312 - 5085244 E-mail: drguldogan@gmail.com

Submitted: 25.02 .2017

Accepted: 14.03.2017

Ulus Travma Acil Cerrahi Derg

20I7;23(6):466-47|

doi: $10.5505 /$ tjtes.2017.16064

Copyright 2017

TJTES organisms from the injured area and microorganism growth in the necrotic tissues resulting from the burn. Burn injuries have a suppressive effect on the immune system; therefore, there is a tendency for endogenous and exogenous infections to increase in these patients. The incidents caused by the state of infection or the progression of infection in burn patients constitute a serious cause of mortality. ${ }^{[1]}$

The aim of this study was to analyze pathogen growth in patients' cultures, confirmed as "infection positive" by the hospital Infection Control Committee, to assess the clinical implications of these growths, to reveal the septic focus, and to examine the relationship of these parameters with mortality.

\section{MATERIALS AND METHODS}

The records of patients hospitalized in the Burn Treatment Center and Burn Intensive Care Unit of our hospital be- 
tween 0I/0I/20I4 and 07/3I/20I5 were reviewed. The admission criteria of the Turkish Burn Treatment Algorithm were followed in all cases. ${ }^{[2]}$ Of the total patients hospitalized between the aforementioned dates, those with late complications of burn and social indications were excluded from the study. Patients included in the study had moderate and major burns with a total burned body surface area of $>10 \%$ and "presence of infection" confirmed by the Infection Control Committee. The patients were evaluated with respect to age, gender, burn etiology, the total body surface area burned (TBSA), the presence of inhalation injury, sepsis, positive wound-blood-urine cultures, the microorganisms cultured, septic focus, and the microorganisms cultured in the septic focus.

In our clinic, the wound, catheter, blood, and urine cultures of patients transferred from other units are sampled once they are hospitalized. These samples are routinely cultured once a week from the intensive care unit (ICU) patients. In non-ICU patients, cultures are taken in the case of an emerging im-

Table I. Grouping of patients by age and etiology of burns

\begin{tabular}{lcc}
\hline & $\mathbf{n}$ & $\%$ \\
\hline Age & & \\
$15-39$ & 19 & 52.8 \\
$40-59$ & 9 & 27.8 \\
$\geq 60$ & 8 & 19.4 \\
Total & 36 & 100 \\
Etiology & & \\
$\quad$ Flame & 26 & 72.2 \\
Scalding & 5 & 13.9 \\
Electrical & 4 & 11.1 \\
Chemical & 1 & 2.8 \\
Total & 36 & 100 \\
\hline
\end{tabular}

paired general condition (such as incongruity, appetite disturbance, decrease in exercise capacity, or behavioral changes) or changes in laboratory values (such as observed in leukopenia, thrombocytopenia, or leukocytosis). Wound swab cultures were taken after wound cleansing during changing of dressings.

The Pearson Chi-square and Student-t tests were used for statistical analysis of the study data. Multivariate analysis was performed using the logistic regression test. A $P$ value of $<0.05$ was considered statistically significant.

\section{RESULTS}

The records of 649 in-patients who met the study criteria were retrospectively evaluated. After excluding patients with minor burns, 349 patients with burned TBSA >10\% constituted the study group. Of these, 36 (10.3\%) patients were confirmed with "infection" by the Infection Control Committee. The incidence of infection on the study date was $11.07 \%$. There were $26(72.2 \%)$ male and $10(27.8 \%)$ female patients with a mean age of $44 \pm 21$ years. Patients in the 15-39 years age group comprised $52.8 \%$ of the patient group (Table I). In the evaluation of burn percentages of the patients, the mean burned TBSA of the whole group was $45.58 \% \pm 23.1 \%$ (range, II\%-94\%), $18.00 \% \pm 5.7 \%$ (range, $11 \%-27 \%$ ) in patients with burned TBSA $<30 \%$, and $57.72 \% \pm 16.2 \%$ (range, $30 \%-94 \%$ ) in patients with $>30 \%$ burned TBSA.

Flame burn was found to have the leading etiology $(n=26$, $72.2 \%$ ), followed by scalding, electrical burn, and chemical burn (Table I).

Acinetobacter baumannii was the most isolated organism in the wound cultures and it was positive in 19 patients, as the single factor of infection in 13 patients $(36.1 \%)$ and among the multiple factors in six patients. Pseudomonas aeruginosa was isolated in 14 wounds. Of these wounds, it was the single factor in eight patients $(22.2 \%)$ and among the multiple factors

Table 2. Microorganisms isolated from wound, blood, and urine cultures

\begin{tabular}{|c|c|c|c|c|c|c|c|c|}
\hline Wound cultures & $\mathbf{n}$ & $\%$ & Blood cultures & $\mathbf{n}$ & $\%$ & Urine cultures & $\mathbf{n}$ & $\%$ \\
\hline A. baumannii & 13 & 36.1 & A. baumannii & 2 & 50 & C. albicans & 4 & 80 \\
\hline P. aeroginosa & 8 & 22.2 & MSSA & I & 25 & P. mirabilis $+A$. baumannii & 1 & 20 \\
\hline MRSA & 1 & 2.8 & P. aeroginosa $+A$. baumannii & 1 & 25 & & & \\
\hline P. aeroginosa $+A$. baumannii & 5 & 13.9 & & & & & & \\
\hline MRSA+ P. aeroginosa & 1 & 2.8 & & & & & & \\
\hline A. baumannii + E. coli & I & 2.8 & & & & & & \\
\hline M. morganii & I & 2.8 & & & & & & \\
\hline C. albicans & I & 2.8 & & & & & & \\
\hline Total & 31 & 100 & & 4 & 100 & & 5 & 100 \\
\hline
\end{tabular}

MRSA: Metisilin resistant Staphylococcus aereus; MSSA: Methisilin sensitive Staphylocaccus aereus. 
Table 3. Growth rates in cultures according to \%TBSA burned

\begin{tabular}{|c|c|c|c|c|c|c|c|c|}
\hline \multirow[t]{2}{*}{ Culture } & & \multicolumn{2}{|c|}{ Total body surface area $<\% 30$} & \multicolumn{2}{|c|}{ Total body surface area $>\% 30$} & \multicolumn{2}{|c|}{ Total } & \multirow[t]{2}{*}{$\mathbf{p}$} \\
\hline & & $\mathbf{n}$ & $\%$ & $\mathbf{n}$ & $\%$ & $\mathbf{n}$ & $\%$ & \\
\hline \multirow[t]{2}{*}{ Blood } & + & 2 & 18.2 & 2 & 8 & 4 & II.I & 0.356 \\
\hline & - & 9 & 81.8 & 23 & 92 & 32 & 88.9 & \\
\hline Total & & II & 100 & 25 & 100 & 36 & 100 & \\
\hline \multirow[t]{2}{*}{ Urine } & + & I & 9.1 & 4 & 16 & 5 & 13.9 & 0.510 \\
\hline & - & II & 90.9 & 21 & 84 & 31 & 86.1 & \\
\hline Total & & 12 & 100 & 25 & 100 & 36 & 100 & \\
\hline \multirow[t]{2}{*}{ Wound } & + & 9 & 81.8 & 22 & 88 & 31 & 86.1 & 0.490 \\
\hline & - & 2 & 18.2 & 3 & 12 & 5 & 13.9 & \\
\hline Total & & 11 & 100 & 25 & 100 & 36 & 100 & \\
\hline
\end{tabular}

in six patients (Table 2 ). The most frequently yielded multiple bacteria were the coexistence of $P$. aeruginosa $+A$. baumannii (13.9\%).

Of the 36 patients with confirmed "infection," blood cultures were positive for infection in 4 (II.I\%). A. baumannii was isolated in $50 \%$ of these patients, followed by methicillin-sensitive Staphylococcus aureus (MSSA) and coexistence of $P$. aeruginosa $+A$. baumannii (Table 2 ). In the study group, 5 (I4\%) patients had positive urine culture. The most frequently isolated microorganism was Candida albicans (80\%) (Table 2).

Eleven (30.6\%) patients had <30\% TBSA burned, whereas 25 (69.4\%) had major extensive burn injuries. The comparison of the cultured microorganisms between these groups is summarized in Table 3.

The overall mortality rate in the study group was $30.56 \%$ (I I/36). There was no mortality in the patients with burned TBSA of $<30 \%$, whereas it significantly increased in patients with burned TBSA of $>30 \%$ (Table 4).

In patients with confirmed infection, there was a statistically significant correlation between the isolation in urine cultures and the mortality rates $(p=0.023$; Table 5$)$. However, no statistically significant difference was found between the blood and wound-borne infections and mortality.

Sepsis was diagnosed in 23 (63.9\%) patients, of whom 2 I had inhalation injuries. There was a significant correlation between inhalation injury and sepsis $(p=0.015)$. In patients with inhalation injury, infection progresses to sepsis at a rate as high as $81 \%$.

Of the patients with sepsis, 10 (45.5\%) died. The presence of sepsis was determined to significantly increase mortality $(p=0.027)$, and the presence of inhalation injury also significantly increased mortality $(p=0.009)$ (Table 5$)$. There was
Table 4. Mortality rates according to the total body surface area burned

\begin{tabular}{lccc}
\hline Total body surface area & \multicolumn{2}{c}{ Mortality } & p \\
\cline { 2 - 3 } & + & - & \\
\hline$<\% 30$ & 0 & 11 & 0.007 \\
$>\% 30$ & II (44\%) & $14(56 \%)$ & \\
\hline
\end{tabular}

Table 5. The relationship between microorganism isolation in cultures, sepsis, and inhalation injury with mortality

\begin{tabular}{|c|c|c|c|c|c|c|}
\hline & & \multicolumn{2}{|c|}{ Mortality + } & \multicolumn{2}{|c|}{ Mortality - } & \multirow[t]{2}{*}{$\mathbf{p}$} \\
\hline & & $\mathbf{n}$ & $\%$ & $\mathbf{n}$ & $\%$ & \\
\hline \multirow[t]{2}{*}{ Blood } & + & 2 & 50 & 2 & 50 & 0.356 \\
\hline & - & 9 & 28.1 & 23 & 71.9 & \\
\hline \multirow[t]{2}{*}{ Urine } & + & 4 & 80 & 1 & 20 & 0.023 \\
\hline & - & 7 & 22.6 & 24 & 77.4 & \\
\hline \multirow[t]{2}{*}{ Wound } & + & 9 & 29 & 22 & 71 & 0.490 \\
\hline & - & 2 & 40 & 3 & 60 & \\
\hline \multirow[t]{2}{*}{ Sepsis } & + & 10 & 43.5 & 13 & 56.5 & 0.027 \\
\hline & - & I & 7.7 & 12 & 92.3 & \\
\hline \multirow[t]{2}{*}{ Inhalation } & + & 10 & 47.6 & II & 52.4 & 0.009 \\
\hline & - & I & 6.7 & 14 & 93.3 & \\
\hline
\end{tabular}

only one case of mortality who did not have sepsis and that patient was in $>30 \%$ TBSA burned group.

The wound itself was the only septic focus in 16 patients. In one patient $(4.3 \%)$, positive culture was determined in the wound, blood, and urine, and this was a fatal case (Table 6). The causes of sepsis are shown in Table 12. A. baumannii was 
the only septic organism isolated in nine patients (39.1\%), followed by $P$. aeruginosa (I3\%) (Table 7).

The organism causing sepsis in cases of isolated focus was determined as $A$. baumannii as the sole cause of infection in the

Table 6. Septic focus

\begin{tabular}{lcc}
\hline Septic focus & $\mathbf{n}$ & $\%$ \\
\hline Wound & 16 & 69.6 \\
Blood & $\mathrm{I}$ & 4.3 \\
Wound-urine & 3 & 13 \\
Wound-blood & $\mathrm{I}$ & 4.3 \\
Blood-urine & $\mathrm{I}$ & 4.3 \\
Wound-blood-urine & $\mathrm{I}$ & 4.3 \\
\hline
\end{tabular}

Table 7. Cause of sepsis

\begin{tabular}{lcc}
\hline Cause of sepsis & $\mathbf{n}$ & $\%$ \\
\hline A. baumannii & 9 & 39.1 \\
P. aeroginosa & 3 & 13 \\
MRSA & 2 & 8.7 \\
C. albicans & $\mathrm{I}$ & 4.3 \\
A. baumannii - P. aeroginosa & 4 & 17.4 \\
A. baumannii - C. albicans & $\mathrm{I}$ & 4.3 \\
MRSA - P. aeroginosa & $\mathrm{I}$ & 4.3 \\
P. aeroginonsa - C. albicans & $\mathrm{I}$ & 4.3 \\
A. baumannii - P. aeroginosa - C. albicans & $\mathrm{I}$ & 4.3 \\
\hline
\end{tabular}

MRSA: Metisilin resistant Staphylococcus aereus. wound, blood, and urine in 9 (39.1\%) patients. In cases with multiple infectious agents, coexistence of $A$. baumannii and $P$. aeruginosa was determined as the cause of sepsis in 4 (17.4\%) patients. Wound was the most frequently encountered septic focus. In 16 (69.6\%) patients, the focus was limited to the burn wound; and the wound site was determined to contribute to sepsis in a total of 21 ( $21 / 23,91.3 \%)$ patients (Table 8$)$.

The Chi-square test was used to determine the significance of the variables of inhalation injury, sepsis, TBSA burned, age, presence of septic focus, and pathogen growth in urine. These independent variables were subjected to logistic regression analysis to determine the variables to be used in the multivariate analysis, which was used to predict the likely effects of prognostic factors on mortality.

In determining the prognostic factors affecting the dependent variable of "survival" in the logistic regression analysis, the Forward Stepwise Selection technique was used. In the model created with all the independent parameters, TBSA was found to be the parameter with the greatest effect on mortality. $\operatorname{Exp}(\beta p)$ values show the odds ratios. The probabilities would have an adverse effect if the $\beta$ coefficients obtained are positive. Based on these results, the level of the surface area burned was found to increase mortality 0.766 fold.

\section{DISCUSSION}

Patients in the 15-39 years age group constituted the vast majority of the study group with "infection" confirmed by the Infection Control Committee. This shows that the time taken for treatment and rehabilitation would cause a serious workforce loss. ${ }^{[3]}$ Those in the 40-59 years age group constituted the second largest group of patients in this study, followed by those aged $\geq 59$ years.

Table 8. The relationship between the culture site and the cause of sepsis

\begin{tabular}{|c|c|c|c|c|c|c|c|c|}
\hline \multirow[t]{2}{*}{ Culture site } & \multirow{2}{*}{$\frac{\mathrm{W}}{\mathrm{n}}$} & \multirow{2}{*}{$\frac{B}{n}$} & \multirow{2}{*}{$\frac{B+U}{n}$} & \multirow{2}{*}{$\frac{\mathbf{W}+\mathbf{U}}{n}$} & \multirow{2}{*}{$\frac{W+B}{n}$} & \multirow{2}{*}{$\frac{\text { All }}{n}$} & \multicolumn{2}{|c|}{ Total } \\
\hline & & & & & & & $\mathbf{n}$ & $\%$ \\
\hline \multicolumn{9}{|l|}{ Cause of sepsis } \\
\hline A. baumannii & 7 & - & 1 & - & I & - & 9 & 39.1 \\
\hline P. aeroginosa & 3 & - & - & - & - & - & 3 & 13 \\
\hline MRSA & I & I & - & - & - & - & 2 & 8.7 \\
\hline C. albicans & - & - & - & 1 & - & - & 1 & 4.3 \\
\hline A. baumannii - $P$. aeroginosa & 4 & - & - & - & - & - & 4 & 17.4 \\
\hline A. baumannii - C. albicans & - & - & - & 1 & - & - & I & 4.3 \\
\hline MRSA - P. aeroginosa & 1 & - & - & - & - & - & 1 & 4.3 \\
\hline P. aeroginosa - C. albicans & - & - & - & $\mathrm{I}$ & - & - & 1 & 4.3 \\
\hline A. baumannii - P. aeroginosa - C. albicans & - & - & - & - & - & 1 & 1 & 4.3 \\
\hline Total, n (\%) & $16(69.6)$ & I (4.3) & I (4.3) & $3(13)$ & I (4.3) & I (4.3) & 23 & 100 \\
\hline
\end{tabular}

W: Wound; B: Blood; B+U: Blood+urine; W+U: Wound+urine, W+B: Wound+blood; MRSA: Metisilin resistant Staphylococcus aereus. 
In recent years, there has been a significant increase in the success rates of burn shock and early resuscitation, with better understanding of burn physiology and developments in both medical monitoring and ICU patient management. This has consequently decreased morbidity and mortality rates. Through the degradation of the integrity of the protective skin barrier due to burn injuries, both endogenous and exogenous access and proliferation of bacteria are facilitated. Furthermore, the necrotic tissue remnants serve as a proliferative medium for microorganisms. The prolonged hospital stay increases the likelihood of exposure to nosocomial infections, which then complicates the treatment of the patient. ${ }^{[4]}$ Although wound infection rates are reduced with appropriate antibiotic selection and rational drug use, wound infection continues to be a cause of sepsis and mortality in burn patients. $^{[1,5,6]}$ The incidence of infection on the study date was I $1.07 \%$. The detected prevalence rates of infected patients (6.9\%) appear to be in line with results of similar studies performed both in Europe and Turkey. ${ }^{[7,8]}$

The application of early excision and grafting as burn management practice is known to reduce the mortality rate in burn patients. ${ }^{[9]}$ In our facility, early excision and grafting has become a standard treatment. However, wound infection and sepsis remain a common problem among hospitalized patients. In the current study, the most common wound infection agents were found to be $A$. baumannii (36.1\%), P. aeruginosa $(22.2 \%)$, and the coexistence of these two (13.9\%). This is similar to data reported by experienced burn centers. [10] These two microorganisms should certainly be considered prior to empirical treatment.

Approximately $10 \%$ of the current study patients diagnosed with infection had positive blood cultures. The organism most commonly isolated in blood cultures was $A$. baumannii, followed by MSSA and the coexistence of $P$. aeruginosa + A. baumannii. These microorganisms have come into prominence as a cause of sepsis in many burn units. ${ }^{\left[{ }^{\prime \prime}\right]}$ Antibiotics should not be used for prophylaxis in burn, because it is well known that prophylactic antibiotic usage leads to colonization of resistant strains. ${ }^{[12]}$ In cases where sepsis is strongly suspected, the initial antibiotic regimen to be delivered until the laboratory results are obtained should cover these organisms.

In the current study, positive urine cultures were observed in $14 \%$ of the patients and C. albicans was isolated in $80 \%$ of the patients. In patients with infection, positive urine cultures significantly increased the mortality rates. Our previous study revealed urinary candidiasis as a more indicative factor for mortality than positive blood culture. ${ }^{[9]}$ Venous blood samples are taken during routine microbiological procedures. Not sampling arterial blood for culture may result in delay for fungal isolation; during this period until fungal findings are determined in the urine, the critical fungal threshold for patients may be reached. However, further studies are required to confirm this hypothesis and because arterial sampling is an invasive procedure, the clinical consequences should be included in the studies.

Inhalation injury is a well-known cause of mortality in burn victims. The presence of inhalation injury in the current study patients significantly increased the mortality rate. On examination of the relationship between the presence of infection and sepsis in patients with inhalation injury, it was concluded that inhalation injury facilitates progression of the infection to sepsis. In this study, the rate of progress to sepsis was found to be $81 \%$ in patients with inhalation injury, thus indicating that presence of inhalation injury in burn patients increases susceptibility to sepsis and this must be taken into consideration in the treatment of burns.

The results of this study showed that development of sepsis is a serious determinant for mortality. Infection with $A$. baumannii, in particular, was found to be a significant factor in in increasing mortality rate. In burn patients considered to have infection or sepsis, the antibiotics to be selected for the period until the culture results are obtained should also cover these microorganisms.

In this study, higher mortality rates were observed in patients with extensive burn injuries and wound infection. However, despite positive wound cultures, no mortality was observed in the group with burned TBSA $<30 \%$. This suggested that in patients with extensive burn injuries, many other factors in addition to wound sepsis could affect mortality. However, as reported previously, ${ }^{[9]}$ an accompanying positive urine culture significantly increases mortality rates. Nonetheless, as a result of the multivariate analysis of patients with "infection" confirmed by the Infection Control Committee, the most prominent factor affecting mortality was determined as the percentage of body surface area burned.

\section{Conclusion}

The infections and sepsis that develop in burn wounds are still a significant cause of mortality in patients with burn injuries. Cases with extensive burn injuries are subjected to multi-systemic effects; therefore, mortality can also occur for various reasons other than wound sepsis. The wounds of these patients should be regularly evaluated, cultures should be taken whenever a wound infection is suspected, and antibiograms should be performed. Antibiotherapies administered should be prescribed according to the antibiogram result, although the possible microorganisms should be previously identified, and the antibiotics to be administered until the antibiogram results are obtained should be decided by taking the clinical flora into consideration. With the use of multivariate analysis in the group studied, the results of the current study demonstrated a greater significance of the body surface area burned, and it should be noted that the presence of urinary tract 
infection and sepsis can be a cause of mortality in patients with burn injuries.

\section{Conflict of interest: None declared.}

\section{REFERENCES}

1. Church D, Elsayed S, Reid O, Winston B, Lindsay R. Burn wound infections. Clin Microbiol Rev 2006;19:403า-34.

2. Yastı AÇ, Şenel E, Saydam M, Özok G, Çoruh A, Yorgancı K. Guideline and treatment algorithm for burn injuries. Ulus Travma Acil Cerrahi Derg 2015;21:79-89. [CrossRef]

3. Sözen İ, Guldogan CE, Kismet K, Sabuncuoğlu MZ, Yasti AÇ. Outpatient burn management and unnecessary referrals. Ulus Travma Acil Cerrahi Derg 2015;21:27-33. [CrossRef]

4. Gomez R, Murray CK, Hospenthal DR, Cancio LC, Renz EM, Holcomb JB, et al. Causes of mortality by autopsy findings of combat casualties and civilian patients admitted to a burn unit. J Am Coll Surg 2009;208:348-54. [CrossRef]

5. Mayhall CG. The epidemiology of burn wound infections: then and now. Clin Infect Dis 2003;37:543-50. [CrossRef]
6. Driscoll JA, Brody SL, Kollef MH. The epidemiology, pathogenesis and treatment of Pseudomonas aeruginosa infections. Drugs 2007;67:35168. [CrossRef]

7. Nicastri E, Petrosillo N, Martini L, Larosa M, Gesu GP, Ippolito G; INFNOS Study Group. Prevalence of nosocomial infections in 15 Italian hospitals: first point prevalance study for the INF-NOS project. Infection 2003;31 Suppl 2:10-5.

8. Klavs I, Bufon Luznik T, Skerl M, Grgic-Vitek M, Lejko Zupanc T, Dolinsek M, et al; Slovenian Hospital-Acquired Infections Survey Group. Prevalance of and risk factors for hospital-acquired infections in Sloveniaresults of the first national survey, 2001.J Hosp Infect 2003;54:149-57.

9. Senel E, Yasti AC, Reis E, Doganay M, Karacan CD, Kama NA. Effects on mortality of changing trends in the management of burned children in Turkey: eight years' experience. Burns 2009;35:372-7. [CrossRef]

10. Raz-Pasteur A, Fishel R, Hardak E, Mashiach T, Ullmann Y, Egozi D. Do wound cultures give information about the microbiology of blood cultures in severe burn patients? Ann Plast Surg 2016;76:34-9. [CrossRef]

11. Glasser JS, Guymon CH, Mende K, Wolf SE, Hospenthal DR, Murray CK. Activity of topical antimicrobial agents against multidrug-resistant bacteria recovered from burn patients. Burns 2010;36:1172-84. [CrossRef]

12. Sözen İ, Güldoğan CE, Yastı AÇ. Etiology of childhood burns and parental awareness in Turkey. Ulus Cerrahi Derg 2015;32:168-72.

\title{
ORIJJINAL ÇALIŞMA - ÖZET
}

\section{Yanık hastalarında klinik enfeksiyonlar ve sonuçları}

\section{Dr. Cem Emir Güldoğan, ${ }^{1}$ Dr. Murat Kendirci, ${ }^{2}$ Dr. Deniz Tikici, ${ }^{3}$ Dr. Emre Gündoğdu, ${ }^{4}$ Dr. Ahmet Çınar Yastı ${ }^{2,3}$}

\author{
${ }^{1}$ Altınbas Üniversitesi Tıp Fakültesi, Genel Cerrahi Anabilim Dalı, İstanbul \\ ${ }^{2}$ Hitit Üniversitesi Tıp Fakültesi, Genel Cerrahi Anabilim Dalı, Çorum \\ ${ }^{3}$ Ankara Numune Eğitim ve Araştırma Hastanesi, Genel Cerrahi Kliniği, Ankara \\ ${ }^{4}$ Bahçeşehir Üniversitesi Tıp Fakültesi, Liv Hospital, Genel Cerrahi Anabilim Dalı, Ankara
}

AMAÇ: Yanık yaralanmaları, koruyucu cilt bariyerinin sürekliliğini bozmakla kalmayıp aynı zamanda sistemik etkiler yoluyla invaziv enfeksiyonları ve sepsisi de kolaylaştııı. Yanık sahası, kan ve idrar örnekleri, patojen ajanı belirlemek için sıklıkla kullanılanılır. Bu çalışmanın amacı, hastane Enfeksiyon Kontrol Komitesi tarafından 'enfeksiyon açısından pozitif' olarak onaylanan hastaların kültüründeki üremeleri analiz etmek ve bu üremelerin klinik etkilerini değerlendirmektir.

GEREÇ VE YÖNTEM: Çalışmaya \% I0'dan fazla yanık yüzey alanı olan ve Enfeksiyon Kontrol Komitesi tarafından "enfeksiyon varlı̆ı” olan yatan hastalar dahil edilidi. Hastalar yaş, cinsiyet, yanık etiyolojisi, toplam yanık vücut alanı (TYVA), inhalasyon hasarı varlığı, sepsis, pozitif kültürler, yarakan-idrar numunelerinden alınan mikroorganizmalar ve septik odak açısından değerlendirildi.

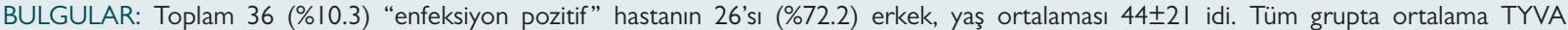
$\% 45.58 \pm 23$. I idi. Acinetobacter baumannii, yara kültürlerinde en fazla izole edilen organizma idi. Enfeksiyon varlığı doğrulanan hastalarda, idrar kültürlerinde izolasyon ile mortalite oranları arasında bir korelasyon vardı $(p=0.023)$. Yirmi üçünde $(\% 63.9)$ sepsis tespit edildi; bunlardan 2 l'inde inhalasyon yaralanması vardı. İnhalasyon hasarı ile sepsis arasında anlamlı bir ilişki vardı $(p=0.015)$ ve hem sepsis hem de inhalasyon yaralanmasının mortaliteyi artırdığı görüldü (sırasıyla, $p=0.027$ ve $p=0.009$ ).

TARTIŞMA: Çalışmanın verilerine göre, yanıklı hastalarda toplam yanıklı vücut yüzey alanı mortalitede daha büyük öneme sahipken, sepsis ve/veya idrar yolu enfeksiyonu varlığı da mortalite nedeni olarak işaret edilmelidir.

Anahtar sözcükler: Acinetobakter baumannii; Candida albicans; enfeksiyon; sepsis.

Ulus Travma Acil Cerrahi Derg 2017;23(6):466-47| doi: 10.5505/tjtes.2017.16064 